\title{
Microwave-Assisted Synthesis and Pharmacological Activity of Pyrazolyl Benzofuran Deravatives
}

\author{
Raghunandan Deshpande ${ }^{1, *}$, Bhagawan Raju $\mathbf{M}^{2}$, Parameshwar $\mathrm{S}^{3}$, Shanth Kumar S.M ${ }^{4}$, Appalaraju S ${ }^{1}$, \\ Manjunath S Yelagatti ${ }^{5}$
${ }^{1}$ H.K.E.S's Matoshree Taradevi Rampure Institute of Pharmaceutical Sciences, Sedam Road, Gulbarga-585105, Karnataka, India ${ }^{2} \mathrm{CM}$ College of Pharmacy, Maisammaguda, Dulapally, Hyderabad-500014, Andhra Pradesh, India ${ }^{3}$ Department of Chemistry, Gulbarga University, Gulbarga 585106, Karnataka, India
${ }^{4}$ V.L. Colleges of Pharmacy, Manik Prabhu Temple Road, Raichur-584102, Karnataka, India ${ }^{5}$ Sri Krupa institute of Pharmaceutical Sciences, Village Velkatta, Siddipet-502277, Medak, Andhra Pradesh, India

\begin{abstract}
Microwave-assisted Organic Reaction Enhancement (MORE) has emerged as a new 'lead' in organic synthesis. During the studies we observed that microwave -assisted organic synthesis requires 2-4 min. of time whereas the conventional ones takes 4-6 hrs and often with poor yields. Hence, with an objective of reducing the reaction time, application of microwave technique has proved to be advantageous in case of synthesis of new benzofuran derivatives. The structures of synthesized derivatives emerged is confirmed by their IR, NMR and Mass spectra. The representative compounds synthesized with this route is further screened for anti-bacterial, analgesic, anti-inflammatory and ulcerogenic studies. In this study we have observed that the benzofuran derivatives are less ulcerogenic compared to phenyl butazone. The structural comparisons have revealed that the chloro substitution will increase the ulcerogenic toxicity.
\end{abstract}

Keywords Analgesic, anti-inflammatory, antimicrobial, microwave-assisted synthesis, pyrazolyl benzofuran, ulcerogenic toxicity

\section{Introduction}

In the recent years, microwave-assisted organic reactions have emerged as a new 'lead' in modern organic synthesis technology[1-5]. Important advantage of this technique is highly accelerated rate of the reaction with improved quality and quantity of the product. The technique offers simple, clean, fast, efficient, and economical and environment friendly method for the synthesis of number of organic molecules. Moreover, the technique is considered as an important 'green chemistry' approach because of its eco-friendly nature[6-9]. Conventional methods of organic synthesis usually need longer heating time, elaborate and tedious apparatus set up, resulting in higher cost of production. Excessive use of solvents/ reagents leads to environmental pollution Efforts are being made to establish the green chemical transformations and to develop several new effective microwave-induced methods for the synthesis of organic compounds[10-12]. The energy used in microwave irradiation is same as that of thermal energy. The advantage in application of this method is its completion in short dura

* Corresponding author:

microraghu@yahoo.co.in (Raghunandan Deshpande)

Published online at http://journal.sapub.org/chemistry

Copyright (c) 2012 Scientific \& Academic Publishing. All Rights Reserved tion and operational simplicity. The use of single frequency microwave oven for this is well established in MORE(Carroet al) (Microwave Induced Organic Reaction Enhancement) chemistry. The experiments like determination of saponification value, loss on drying could be performed within minutes[13,14].

Pyrazolobenzofurans which carried off only synthetic interest, initially, are now finding greater importance as biologically active molecules[15]. Some of these compounds are reported to possess bactericidal, anti-viral and anti-cancer activity[16,17]. Annulation of pyrazole ring system on benzofuran nucleus has resulted in compounds possessing analgesic and anticonvulsant activities[18]. In view of these findings, we focused our interest on benzofuran coupled with pyrazole for our research program. The carbonyl hydrazide is used for the development of pyrazole ring system (as quoted in literature for having best functionality). The synthetic strategy that involves the modification of carbonyl hydrazide group located on the furan moiety of benzofuran nucleus in to the desired pyrazole ring system. 3- methoxy-2-carbohydrazide has chosen for this investigation. The reaction on condensation of benzofuran-2-carbonylhydrazide with different acetones and chloroacetones and further treated with DMF and $\mathrm{POCl}_{3}$ under microwave irradiation. Benzofuran-2-carbonyl hydrazine and pyrazoles are biologically active, synthetically useful and important heterocyclic compounds[19,20]. In 
view of this, we report here the microwave assisted synthesis of pyrazolyl benzofurans and screened for different pharmacological activities.

\section{Materials and Methods}

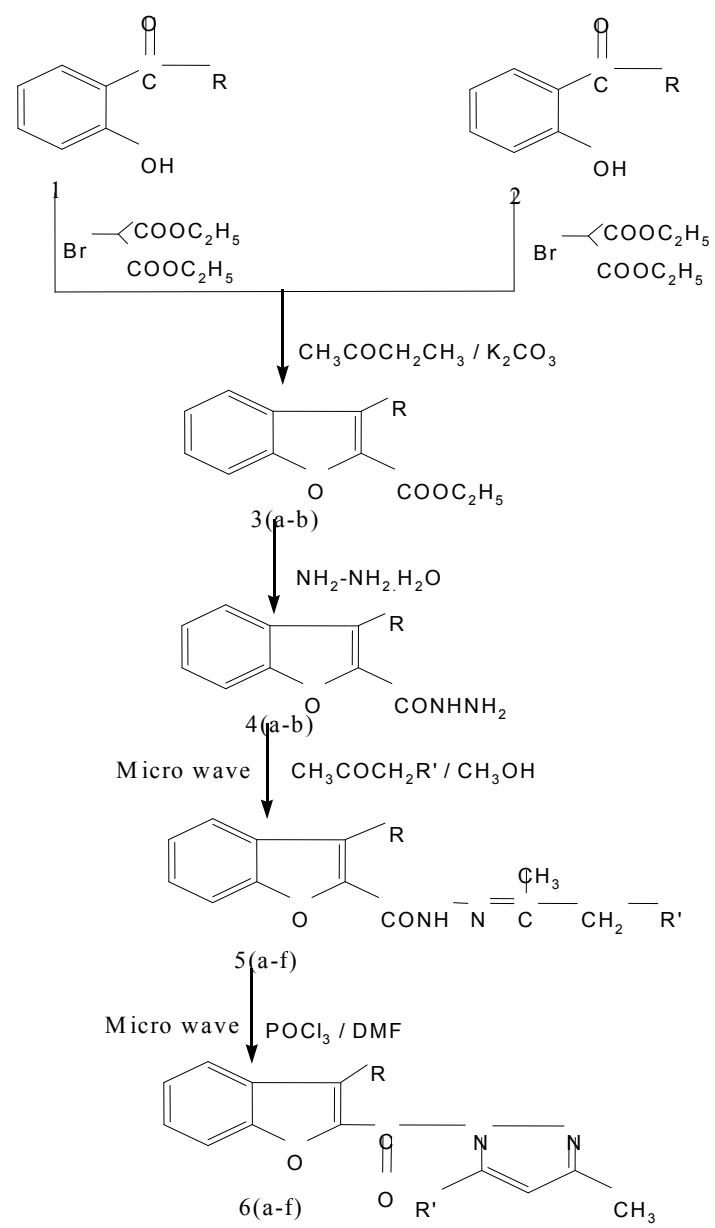

Scheme 1. Microwave mediated synthesis of different pyrazolyl benzofuran derivatives from Benzofuran-2-carbohydrazide

All the chemicals used for the synthesis are of AR grade and obtained from Qualigens fine Chemicals and carragenin $1 \%$ (in normal saline) solution prepared from the gift samples obtained from R\&D section of Micro labs Ltd, Bangalore. Samsung, $450 \mathrm{MHz}$ single frequency instrument is used for the microwave-assisted synthesis of pyrazolyl benzofuran derivatives. Melting points are in degree centigrade. These were determined in open capillary tubes and are uncorrected. The synthesized compounds were purified, recrystalized and subjected to FTIR measurements carried on a Perkin-Elmer Spectrum-One instrument at a resolution of 4 $\mathrm{cm}^{-1}$ in $\mathrm{KBr}$ pellets. PMR spectra were recorded using $90 \mathrm{MHz}$ FX - 909 JEOL spectrophotometers using TMS as internal standard and the solvent used is $\mathrm{CDCl} 3$. Mass spectra were recorded on Finnigan-Mat 1020 (EI, 70 ev). Micro-organisms sub cultures were procured from the Department of Microbiology, Gulbarga University Gulbarga (pure cultures were obtained from IMTECH, Chandigarh).
Synthesis of 3-ethylsubstitutedbenzofuran-2-carbohydraz ide 4(a-b)

Benzofuran-2-carbohydrazide was prepared initially by dimethylmalonate $(0.01 \mathrm{~mol})$ and 2-carboxybenzofuran $(0.01 \mathrm{~mol})$ (Scheme) with hydrazine hydrate $(5 \mathrm{ml}, 99 \%)$ in ethanol $(30 \mathrm{ml})$. The mixture was magnetically stirred at room temperature for $12 \mathrm{hrs}$. IR OF 4a: 3341, 3160 NHNH2 and $1667 \quad \mathrm{C}=\mathrm{O} \quad \mathrm{cm}-1 . \quad 1 \mathrm{H} \quad \mathrm{NMR} \quad \mathrm{OF} \quad 4 \mathrm{a}: \quad \delta$ 6.5-7.4(m, ArH),8.2(s,NH2),2.4(s, NH). Mass spectrum of 4a: $\mathrm{m} / \mathrm{z}=176$. IR OF $4 \mathrm{~b}: 3313,3220 \mathrm{NHNH} 2$ and $1627 \mathrm{C}=\mathrm{O}$ $\mathrm{cm}-1$. 1H NMR of $4 \mathrm{~b}: \delta 6.0-7.1$ (m, ArH), 8.0 (s,NH2), 2.2 (s, $\mathrm{NH}), 3.7$ (s, -CH2). Mass spectrum of $4 \mathrm{~b}: \mathrm{m} / \mathrm{z}=206$.

General procedure for synthesis of N'-(3-substitutedprop ylen-2-ylidene)-3-substituted benzofuran-2-carbohydrazide 5 (a-f)

A mixture of benzofuran-2-carbazide $(0.01 \mathrm{~mol})$ and acetophenone $(0.01 \mathrm{~mol})$ with few drops of glacial acetic acid was taken in $100 \mathrm{ml}$ conical flask capped with funnel. The flask was incubated in a microwave at 100watts for $2 \min 30$ sec. The reaction mixture is cooled; the solid thus separated was filtered and recrystalized using methanol. IR of $5 \mathrm{a}: 3341$, $3160 \mathrm{NHNH} 2$ and $1667 \mathrm{C}=\mathrm{O} \mathrm{cm}-1$. 1H NMR 5a: $\delta$ 6.5-7.4(m, ArH),8.2(s,NH2),2.4(s, NH). Mass spectrum of 5a: $\mathrm{m} / \mathrm{z}=176$. IR of $5 \mathrm{~b}: 3313,3220 \mathrm{NHNH} 2$ and $1627 \mathrm{C}=\mathrm{O} \mathrm{cm}-1$. 1H NMR of 5b: $\delta 6.0-7.1$ (m, ArH), 8.0 (s,NH2), $2.2(\mathrm{~s}, \mathrm{NH})$, 3.7 (s, -CH2). Mass spectrum of of $5 \mathrm{~b}: \mathrm{m} / \mathrm{z}=206$. IR of $5 \mathrm{c}$ : $3160 \mathrm{NH} 2$ and $1657 \mathrm{C}=\mathrm{O} \mathrm{cm}-1.1 \mathrm{H}$ NMR of $5 \mathrm{c}: \delta 6.5-7.5(\mathrm{~m}$, $\mathrm{ArH}), 7.8(\mathrm{~s}, \mathrm{NH}), 1.4(\mathrm{~s}, \mathrm{NH}), 2.6(\mathrm{~s}, \mathrm{CH} 2)$. Mass spectrum of $5 \mathrm{c}: \mathrm{m} / \mathrm{z} 328,329$. IR $5 \mathrm{~d}: 3160 \mathrm{NH} 2$ and $1657 \mathrm{C}=\mathrm{O} \mathrm{cm}-1$. 1H NMR 5d: $\delta 6.5-7.5$ (m, ArH), $7.8(\mathrm{~s}, \mathrm{NH}), 1.4(\mathrm{~s}, \mathrm{NH}), 2.6$ (s, CH2). Mass spectrum of $5 \mathrm{~d}: \mathrm{m} / \mathrm{z} 260$. IR of $5 \mathrm{e}: 3160 \mathrm{NH} 2$ and $1657 \mathrm{C}=\mathrm{O} \mathrm{cm}-1.1 \mathrm{H}$ NMR of $5 \mathrm{e}: \delta 6.5-7.5(\mathrm{~m}, \mathrm{ArH}), 7.8$ $(\mathrm{s}, \mathrm{NH}), 1.4(\mathrm{~s}, \mathrm{NH}), 2.6(\mathrm{~s}, \mathrm{CH} 2)$. Mass spectrum of $5 \mathrm{e}: \mathrm{m} / \mathrm{z}$ 322.IR of $5 \mathrm{f}: 3160 \mathrm{NH} 2$ and $1657 \mathrm{C}=\mathrm{O} \mathrm{cm}-1$. $1 \mathrm{H}$ NMR of $5 \mathrm{f}$ : $\delta$ 6.5-7.5 (m, ArH), $7.8(\mathrm{~s}, \mathrm{NH}), 1.4(\mathrm{~s}, \mathrm{NH}), 2.6(\mathrm{~s}, \mathrm{CH} 2)$. Mass spectrum of $5 \mathrm{f}: \mathrm{m} / \mathrm{z} 358,359$.

General procedure for synthesis of (3-substituted-5substit uted-1H-pyrazol-1-yl)(3-substituted benzofu ran-2-yl)metha none $6(\mathrm{a}-\mathrm{f})$

To the Vilsmeier - Hack complex, prepared from DMF $(10 \mathrm{ml})$ and $\mathrm{POCl} 3(0.012 \mathrm{~mol})$ in a conical flask at $0 \mathrm{oC}$ the hydrazone $(0.01 \mathrm{~mol})$ was added and capped with funnel. The reaction mixture was irradiated in microwave oven at 100 watts for 3 minutes. The reaction mixture quenched by pouring on to the crushed ice. The product which is separated on neutralization with $\mathrm{NaHCO} 3$ was filtered, washed with water and recrystalized with methanol. The 4-chloro derivative is prepared similarly and their characterization data is recorded. IR 6a: $3160 \mathrm{NH} 2$ and $1657 \mathrm{C}=\mathrm{O} \mathrm{cm}-1.1 \mathrm{H} \mathrm{NMR}$ 6a: $\delta$ 6.5-7.5 (m, ArH), 7.8 (s, NH), $1.4(\mathrm{~s}, \mathrm{NH}), 2.6(\mathrm{~s}, \mathrm{CH} 2)$. Mass spectrum 6a: m/z 240. IR 6b: $3160 \mathrm{NH} 2$ and $1657 \mathrm{C}=\mathrm{O}$ cm-1. 1H NMR 6b: $\delta$ 6.5-7.5 (m, ArH), $7.8(\mathrm{~s}, \mathrm{NH}), 1.4(\mathrm{~s}$, $\mathrm{NH}), 2.6$ (s, CH2). Mass spectrum $6 \mathrm{~b}: \mathrm{m} / \mathrm{z} 302$. IR 6c: 3160 $\mathrm{NH} 2$ and $1657 \mathrm{C}=\mathrm{O} \mathrm{cm}-1.1 \mathrm{H}$ NMR $6 \mathrm{c}: \delta$ 6.5-7.5 (m, ArH), $7.8(\mathrm{~s}, \mathrm{NH}), 1.4(\mathrm{~s}, \mathrm{NH}), 2.6(\mathrm{~s}, \mathrm{CH} 2)$. Mass spectrum $6 \mathrm{c}: \mathrm{m} / \mathrm{z}$ 336, 337. IR 6d: $3160 \mathrm{NH} 2$ and $1657 \mathrm{C}=\mathrm{O} \mathrm{cm}-1.1 \mathrm{H} \mathrm{NMR}$ 6d: $\delta$ 6.5-7.5 (m, ArH), 7.8 (s, NH), $1.4(\mathrm{~s}, \mathrm{NH}), 2.6$ (s, CH2). 
Mass spectrum 6d: $\mathrm{m} / \mathrm{z} 271$. IR 6e: $3160 \mathrm{NH} 2$ and $1657 \mathrm{C}=\mathrm{O}$ cm-1. 1H NMR 6e: $\delta$ 6.5-7.5 (m, ArH), $7.8(\mathrm{~s}, \mathrm{NH}), 1.4(\mathrm{~s}$, $\mathrm{NH}), 2.6$ (s, CH2). Mass spectrum 6e: $\mathrm{m} / \mathrm{z}$ 333. IR 6f: 3160 $\mathrm{NH} 2$ and $1657 \mathrm{C}=\mathrm{O} \mathrm{cm}-1.1 \mathrm{H}$ NMR $6 \mathrm{f}: \delta$ 6.5-7.5 (m, ArH), $7.8(\mathrm{~s}, \mathrm{NH}), 1.4(\mathrm{~s}, \mathrm{NH}), 2.6$ (s, $\mathrm{CH} 2)$. Mass spectrum $6 \mathrm{f}: \mathrm{m} / \mathrm{z}$ $336,337$.

In vitro studies

Antibacterial activity

In vitro antibacterial activities of the representative derivatives of benzofuran, $6 \mathrm{~b}, 6 \mathrm{c}, 6 \mathrm{e}$ and $6 \mathrm{f}$ compounds were analyzed against two gram-positive and two gram negative bacteria, by broth dilution method as per the national standards[21,22]. The microorganisms were revived by inoculating in broth media and grown at $37^{\circ} \mathrm{C}$ for $18 \mathrm{hrs}$, harvested by centrifugation, and then washed several times with fresh deionised water. Stock solutions of the series of compounds were prepared in DMSO. Potato Dextrose Agar (PDA) media was used. The compound used was in a concentration of $1,5,10$ and $25 \mu \mathrm{g}$ per $0.1 \mathrm{ml}$. All the plates were incubated at $37^{\circ} \mathrm{C}$ for $48 \mathrm{~h}$ and the minimum inhibitory concentration of the respective compounds against the representative micro-organism was determined.

Antifungal activity

The stock cultures of Candida albicans, Aspergillus fumigatus were revived by inoculating in broth media and incubating at $27^{\circ} \mathrm{C}$ for $48 \mathrm{hrs}$. Potato Dextrose Agar media was used. The compound used was in a concentration of 1,5 ,
10 and $25 \mu \mathrm{g}$ per $0.1 \mathrm{ml}$. All the plates were incubated at $37^{\circ} \mathrm{C}$ for $48 \mathrm{~h}$ and the minimum inhibitory concentration of the respective compounds against the representative micro-organism was determined.

In vivo Studies

The animals were procured from the animal house of M.R. Medical College, were kept at ambient temperature, and had free access to water and diet. The animal experiments were carried in accordance with the guidelines of Institutional Animal Ethics Committee.

\section{Anti-inflammatory Activity}

Anti-inflammatory Activity is determined by the rat hind paw method according to[22]. Albino rats of either sex weighing 175 to $185 \mathrm{gm}$ were selected and divided into six each and fasted for $24 \mathrm{hrs}$ prior to experiment with water ad libitum. The edema was induced by injecting $1 \%$ caragenin into the plantar surface of the hind paw of rats. The first group was given the acacia suspension (control) and the other group was administered with Phenylbutazone as a standard $(50 \mathrm{mg} / \mathrm{kg}$ I.P.). The animals of group 3 to 6 were given 4 representative analogues of pyrazolyl benzofuran at a dose of $200 \mathrm{mg} / \mathrm{kg}$. The reaction time of each rat was recorded at the interval of $0,1 / 2 \mathrm{~h}, 1 \mathrm{~h}, 2 \mathrm{~h}, 4 \mathrm{~h}$ and $6 \mathrm{~h}$ of time interval. The paw edema was measured by plethysmograph. Mean volume in the paw is measured and the percentage inhibition was calculated using following formula.

Table 1. Physical constants and elemental analyses of the compounds 4 (a-b), 5(a-f) and 6(a-f) compounds

\begin{tabular}{|c|c|c|c|c|c|c|c|c|}
\hline \multirow{2}{*}{ Comp No. } & \multirow{2}{*}{$\mathrm{R}$} & \multirow{2}{*}{$\mathrm{R}^{\prime}$} & \multirow{2}{*}{ Yield \% } & \multirow{2}{*}{ M.P. oC } & \multirow{2}{*}{$\begin{array}{l}\text { Mol.Formula } \\
\text { (Mol Wt) }\end{array}$} & \multicolumn{3}{|c|}{ Microanalysis $\%$ calc \& found } \\
\hline & & & & & & $\mathrm{C}$ & $\mathrm{H}$ & $\mathrm{N}$ \\
\hline \multirow{2}{*}{$4 a$} & \multirow{2}{*}{$\mathrm{H}$} & \multirow{2}{*}{-} & \multirow{2}{*}{62} & \multirow{2}{*}{ 163-165 } & $\mathrm{C}_{9} \mathrm{H}_{8} \mathrm{~N}_{2} \mathrm{O}_{2}$ & 61.36 & 4.58 & 15.86 \\
\hline & & & & & $(176)$ & 61.30 & 4.53 & 15.86 \\
\hline \multirow{2}{*}{$4 b$} & \multirow{2}{*}{$\mathrm{OCH}_{3}$} & \multirow{2}{*}{-} & \multirow{2}{*}{60} & \multirow{2}{*}{$110-112$} & $\mathrm{C}_{10} \mathrm{H}_{10} \mathrm{~N}_{2} \mathrm{O}_{3}$ & 58.25 & 4.89 & 13.59 \\
\hline & & & & & $(206)$ & 58.20 & 4.82 & 13.55 \\
\hline \multirow{2}{*}{$5 \mathbf{a}$} & \multirow{2}{*}{$\mathrm{H}$} & \multirow{2}{*}{$\mathrm{CH}_{3}$} & \multirow{2}{*}{74} & \multirow{2}{*}{$200-202$} & $\mathrm{C}_{13} \mathrm{H}_{14} \mathrm{~N}_{2} \mathrm{O}_{2}$ & 67.81 & 6.13 & 12.17 \\
\hline & & & & & $(230)$ & 67.80 & 6.10 & 12.80 \\
\hline \multirow{2}{*}{$5 b$} & \multirow{2}{*}{$\mathrm{H}$} & \multirow{2}{*}{$\mathrm{C}_{6} \mathrm{H}_{5}$} & \multirow{2}{*}{71} & \multirow{2}{*}{$200-202$} & $\mathrm{C}_{18} \mathrm{H}_{16} \mathrm{~N}_{2} \mathrm{O}_{2}$ & 73.95 & 5.52 & 9.58 \\
\hline & & & & & $(292)$ & 73.90 & 5.48 & 9.55 \\
\hline \multirow[b]{2}{*}{$5 c$} & \multirow[b]{2}{*}{$\mathrm{H}$} & \multirow{2}{*}{$\mathrm{C}_{6} \mathrm{H}_{4} \mathrm{Cl}(\mathrm{p})$} & & & $\mathrm{C}_{18} \mathrm{H}_{15} \mathrm{~N}_{2} \mathrm{O}_{2} \mathrm{Cl}$ & 66.16 & 4.63 & 8.57 \\
\hline & & & 66 & $200-202$ & $(326)$ & 66.10 & 4.60 & 8.55 \\
\hline & & & & $200-202$ & $\mathrm{C}_{18} \mathrm{H}_{15} \mathrm{~N}_{2} \mathrm{O}_{2}$ & 64.6 & 6.20 & 10.76 \\
\hline $5 d$ & $\mathrm{OCH}_{3}$ & $\mathrm{CH}_{3}$ & 78 & $200-202$ & $(291)$ & 64.55 & 6.15 & 10.75 \\
\hline $5 e$ & $\mathrm{OCH}_{3}$ & $\mathrm{C}_{6} \mathrm{H}_{5}$ & 70 & $200-202$ & $\mathrm{C}_{14} \mathrm{H}_{16} \mathrm{~N}_{2} \mathrm{O}_{3}$ & 70.79 & 5.63 & 8.69 \\
\hline se & $\mathrm{OCH}_{3}$ & $\mathrm{C}_{6} \mathrm{H}_{5}$ & 10 & $200-202$ & $(260)$ & 70.71 & 5.60 & 8.65 \\
\hline & & & & & $\mathrm{C}_{19} \mathrm{H}_{18} \mathrm{~N}_{2} \mathrm{O}_{3}$ & 63.96 & 4.80 & 7.85 \\
\hline $5 f$ & $\mathrm{OCH}_{3}$ & $\mathrm{C}_{6} \mathrm{H}_{5}$ & 81 & $200-202$ & $(322)$ & 63.90 & 4.75 & 7.80 \\
\hline & & & & & $\mathrm{C}_{19} \mathrm{H}_{17} \mathrm{~N}_{2} \mathrm{O}_{3}$ & 69.99 & 5.03 & 11.66 \\
\hline $\mathbf{b a}$ & $\mathrm{H}$ & $\mathrm{CH}_{3}$ & 81 & $200-202$ & (321) & 69.95 & 5.00 & 11.64 \\
\hline & & & & & $\mathrm{C}_{19} \mathrm{H}_{14} \mathrm{~N}_{2} \mathrm{O}_{2}$ & 75.48 & 4.67 & 9.27 \\
\hline $6 \mathbf{b}$ & $\mathrm{H}$ & $\mathrm{C}_{6} \mathrm{H}_{5}$ & 63 & 200-202 & $(302)$ & 75.40 & 4.65 & 9.25 \\
\hline $6 c$ & $\mathrm{H}$ & $\mathrm{C}_{\mathrm{H}_{2} \mathrm{Cl}}(\mathrm{n})$ & 65 & $200-202$ & $\mathrm{C}_{19} \mathrm{H}_{13} \mathrm{~N}_{2} \mathrm{O}_{2} \mathrm{Cl}$ & 67.76 & 3.89 & 8.32 \\
\hline oc & $\mathrm{H}$ & $\mathrm{C}_{6} \mathrm{H}_{4} \mathrm{Cl}(\mathrm{p})$ & 65 & $200-202$ & (336) & 67.71 & 3.85 & 8.30 \\
\hline & & & & & $\mathrm{C}_{15} \mathrm{H}_{14} \mathrm{~N}_{2} \mathrm{O}_{3}$ & 66.66 & 5.22 & 10.36 \\
\hline $6 d$ & $\mathrm{OCH}_{3}$ & $\mathrm{CH}_{3}$ & 88 & $200-202$ & $(270)$ & 66.60 & 5.20 & 10.33 \\
\hline $6 e$ & $\mathrm{OCH}_{2}$ & $\mathrm{C}_{5} \mathrm{H}_{5}$ & 86 & $200-202$ & $\mathrm{C}_{20} \mathrm{H}_{16} \mathrm{~N}_{2} \mathrm{O}_{3}$ & 72.28 & 4.85 & 8.43 \\
\hline Oc & $\mathrm{CH}_{3}$ & $\mathrm{C}_{6} \Pi_{5}$ & 80 & $200-202$ & (332) & 72.20 & 4.80 & 8.40 \\
\hline $6 f$ & & $\mathrm{CH}$ & 81 & 200-200 & $\mathrm{C}_{20} \mathrm{H}_{15} \mathrm{~N}_{2} \mathrm{O}_{3} \mathrm{Cl}$ & 65.49 & 4.12 & 7.64 \\
\hline bI & $\mathrm{CH}_{3}$ & $\mathrm{C}_{6} \mathrm{H}_{4} \mathrm{Cl}(\mathrm{p})$ & 81 & $200-202$ & (367) & 65.45 & 4.08 & 7.62 \\
\hline
\end{tabular}


Percentage inhibition $=100-(1-\mathrm{VT} / \mathrm{VC})$

Whereas $\mathrm{VC}=$ Edema volume in control

$\mathrm{VT}=$ Edema volume in test / standard compound

Analgesic activity

Eddy's hot plate method is adopted[23]. Preliminary experiments were conducted to select the rat which showed a reaction time of 2 to 4 seconds. The results of analgesic screening are summarized in Table. The cut-off point of 10 sec was strictly practiced to avoid any damage to the paws.

Acute ulcerogenesis

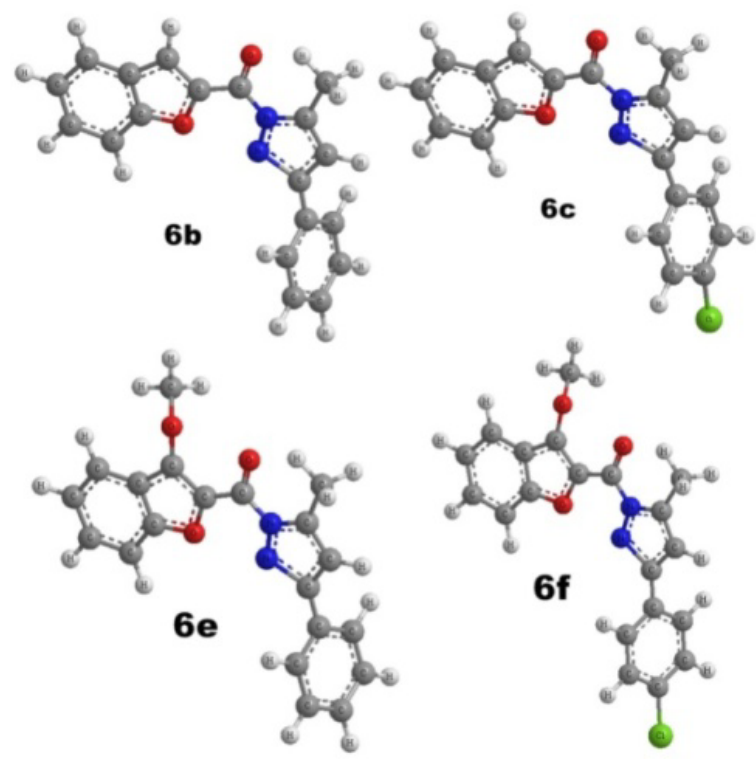

The procedure is followed as per given in[24]. Albino rats (175-185 g) were divided into different groups consisting of six animals in each group. Ulcerogenic activity evaluated after the administration of test compounds or Phenyl butazone at the dose of $50 \mathrm{mg} / \mathrm{kg}$. Control rats received administration of vehicle (suspension of $2 \%$ acacia). Food but not water was removed $24 \mathrm{~h}$ before administration of the test compounds. After the drug treatment, the rats were fed normal diet for $17 \mathrm{~h}$ and then sacrificed. The stomach was removed and opened along the greater curvature, washed with distilled water and opened along the greater curvature, washed with distilled water and cleaned gently by dipping in saline. The gastric mucosa of the rats was examined using 10X microscope. The lesions were checked, counted and categorized into perforated (greater than $2 \mathrm{~mm}$ in diameter), average (1-2 $\mathrm{mm}$ ) and small (less than $1 \mathrm{~mm})$. For each stomach the severity of mucosal damage was assessed according to the following scoring system. The mean score of each treated group minus the mean score of the control group was considered as the 'ulcer index' of gastric damage. The score on the performance of the respective compounds based upon their ulcerative response i.e., more the score less the ulcerogenic response.

\section{Results and Discussions}

The derivative obtained from pyrazolylbenzofuran basic nucleus in two step synthesis, their structures was confirmed by IR, 1HNMR and Mass spectra. For brevity only 4 synthesized derivatives which have shown satisfactory in-vitro and in-vivo biological activities were reported.

In vitro activity

Anti-bacterial \& anti-fungal activity

In the series, representative compounds $6 \mathrm{~b}, 6 \mathrm{c}, 6 \mathrm{e}$ and $6 \mathrm{f}$ analyzed is shown in table 2 . The compound $6 \mathrm{f}$ is highly active against all the gram-positive bacteria and gram negative bacteria, the compound $6 \mathrm{c}$ were active against $\mathrm{B}$. subtilis. It is interesting to note that the compounds which were substituted with chloro at 4 th position of pyrazolyl ring, displayed notable antibacterial activity.

In anti-fungal analysis, compound $6 \mathrm{f}$ has shown satisfactory activity against Candida albicans and moderate activity against Aspergillus fumigatus. All other compounds (6b, 6cand 6e) did not indicate any positive sign in this experiment.

In vivo activity

Anti- inflammatory activity \& Analgesic activity

The pharmacological screening of the tested compounds showed anti-inflammatory activity ranging from 38.33 to $78.11 \%$ (Table 3), whereas the standard drug phenylbutazone showed 79.5\% inhibition after $4 \mathrm{~h}$. The anti-inflammatory activity of pyrazolylbenzofuran derivatives synthesized using microwave exposure of compound $6 \mathrm{~b}, 6 \mathrm{c}, 6 \mathrm{e}$ and $6 \mathrm{f}$ ranged from 52.5 to $74.5 \%$. The compounds $6 \mathrm{c}$ and $6 \mathrm{f}$ which are chloro substituted showed higher activity than the standard drug phenylbutazone, whereas in the compound $6 \mathrm{~b}$, the anti-inflammatory activity decreased. Also, it was observed that the compound 6e showed activity ranging from 48.1 to $66.63 \%$, which is nearly equivalent to the standard drug phenylbutazone. It is clear from Table that the presence of 3-methoxy group and further chloro substitution at 4 th position increases the anti-inflammatory activity.

All the four compounds have anti-inflammatory activity than those of the standard were further tested for their analgesic activity at a dose of $50 \mathrm{mg} \mathrm{kg}-1$ phenylbutazone (Table. 1). Compounds showed analgesic activity ranging from 58.4 to $72.7 \%$, whereas the standard drug ibuprofen showed $69.5 \%$ inhibition. The results followed the path equal to that of analgesic activity as the chloro substitution even in this case enhanced the analgesic activity, however with a degree of variation.

Ulcerogenic activity

It is noted that though the antimicrobial, analgesic and anti-inflammatory activities increased with chloro substitutions on pyrazolyl ring system the ulcerogenicity profile is also slightly increased (Table 4). The toxicity profile is almost negligible on comparison with standard drug phenylbutazone. The compounds $6 \mathrm{~b}$ and $6 \mathrm{e}$ which had shown moderate analgesic and anti-inflammatory activity had shown nil GI perforations. 
Table 2. Anti-microbial data of $6 \mathrm{~b}, 6 \mathrm{c}, 6 \mathrm{e}$ and $6 \mathrm{f}$

\begin{tabular}{|c|c|c|c|c|c|c|c|}
\hline \multicolumn{5}{|c|}{$=$ Anti-bacterial activity } & \multicolumn{3}{|c|}{ Anti-fungal Activity } \\
\hline \multicolumn{8}{|c|}{ Minimum inhibitory concentration (MIC, $\mu \mathrm{g} / \mathrm{mL}$ ) } \\
\hline & \multicolumn{2}{|c|}{ Gram +ve } & \multicolumn{2}{|c|}{ Gram -ve } & & \multirow[b]{2}{*}{ C.albicans } & \multirow[b]{2}{*}{ A.fumigatus } \\
\hline & B.subtilis & S.aureus & P.aerosenosa & K.aerogenes & & & \\
\hline $6 \mathrm{~b}$ & 75 & 50 & --- & 50 & $6 \mathrm{~b}$ & 75 & --- \\
\hline $6 \mathrm{c}$ & 25 & 50 & 75 & 50 & $6 \mathrm{c}$ & 50 & --- \\
\hline $6 e$ & 75 & 75 & --- & 50 & $6 e$ & 75 & --- \\
\hline $6 f$ & 25 & 25 & 75 & 25 & $6 f$ & 25 & 75 \\
\hline Streptomycin & 5 & 10 & 2.5 & 5 & Amphoterisin B & 5 & 2.5 \\
\hline
\end{tabular}

Microorganisms: Bacillus subtilis MTCC 441; Staphylococcus aureus MTCC 96; Pseudomonas aeruginosa MTCC 741; Klebsiella aerogenes MTCC 39 (---) no inhibition zone

Candida albicans ATCC 19231; Aspergillus fumigatus HIC 6094

\begin{tabular}{|c|c|c|c|c|c|c|c|c|c|c|c|c|c|c|}
\hline \multirow[t]{3}{*}{$\mathrm{Gr}$} & \multirow[t]{3}{*}{ Compd. } & \multirow[t]{3}{*}{$\begin{array}{l}\text { Admn. } \\
\mathrm{mg} / \mathrm{Kg}\end{array}$} & \multicolumn{6}{|c|}{ Analgesic activity } & \multicolumn{6}{|c|}{$\begin{array}{l}\text { Anti-inflammatory Activity on carrageenan induced } \\
\text { rat paw edema }\end{array}$} \\
\hline & & & \multicolumn{6}{|c|}{ Mean response in Hour \& \% of Inhibition } & \multicolumn{6}{|c|}{$\%$ of Inhibition in Hour } \\
\hline & & & $0 \mathrm{hr}$ & $1 / 2 \mathrm{hr}$ & $1 \mathrm{hr}$ & $2 \mathrm{hr}$ & $4 \mathrm{hr}$ & $6 \mathrm{hr}$ & $0 \mathrm{hr}$ & $1 / 2 \mathrm{hr}$ & $1 \mathrm{hr}$ & $2 \mathrm{hr}$ & $4 \mathrm{hr}$ & $6 \mathrm{hr}$ \\
\hline $\mathrm{I}$ & Control & - & $\begin{array}{c}0.2 \pm \\
0.05\end{array}$ & $\begin{array}{c}0.33 \pm \\
0.04\end{array}$ & $\begin{array}{c}0.37 \pm \\
0.06\end{array}$ & $\begin{array}{c}0.34 \pm \\
0.06\end{array}$ & $\begin{array}{c}0.35 \pm \\
0.06\end{array}$ & $\begin{array}{c}0.26 \pm \\
0.07\end{array}$ & & & & & & \\
\hline & & & --- & --- & --- & --- & --- & --- & --- & -- & --- & --- & --- & --- \\
\hline II & $\begin{array}{c}\text { Phenyl } \\
\text { butazone }\end{array}$ & 50 & $\begin{array}{c}0.20 \pm \\
0.05 \\
(39 \%)\end{array}$ & $\begin{array}{c}0.13 \pm \\
0.04 \\
(58 \%)\end{array}$ & $\begin{array}{c}0.16 \pm \\
0.01 \\
(56 \%)\end{array}$ & $\begin{array}{c}0.17 \pm \\
0.03 \\
(35 \%)\end{array}$ & $\begin{array}{c}0.16 \pm \\
0.02 \\
(55 \%)\end{array}$ & $\begin{array}{c}0.15 \pm \\
0.01 \\
(58 \%)\end{array}$ & 46.65 & 50.01 & 56.12 & 58.22 & 62.66 & 61.01 \\
\hline III & $6 b$ & 200 & $\begin{array}{c}0.15 \pm \\
0.01 \\
(54 \%)\end{array}$ & $\begin{array}{c}0.15 \pm \\
0.01 \\
(54 \%)\end{array}$ & $\begin{array}{c}0.11 \pm \\
0.03 \\
(70 \%)\end{array}$ & $\begin{array}{c}0.13 \pm \\
0.03 \\
(60 \%)\end{array}$ & $\begin{array}{c}0.12 \pm \\
0.03 \\
(65 \%)\end{array}$ & $\begin{array}{c}0.12 \pm \\
0.03 \\
(65 \%)\end{array}$ & 38.3 & 41.17 & 44.43 & 46.42 & 49.34 & 48.14 \\
\hline IV & $6 c$ & 200 & $\begin{array}{c}0.13 \pm \\
0.02 \\
(63 \%)\end{array}$ & $\begin{array}{c}0.14 \pm \\
0.02 \\
(57 \%)\end{array}$ & $\begin{array}{c}0.13 \pm \\
0.03 \\
(65 \%)\end{array}$ & $\begin{array}{c}0.16 \pm \\
0.02 \\
(55 \%)\end{array}$ & $\begin{array}{c}0.12 \\
\pm .02 * \\
(65 \%)\end{array}$ & $\begin{array}{c}0.13 \pm \\
0.03 \\
(62 \%)\end{array}$ & 52.5 & 62.06 & 64.03 & 65.58 & 66.63 & 64.86 \\
\hline $\mathrm{V}$ & $6 e$ & 200 & $\begin{array}{c}0.09 \pm \\
0.04 \\
(57 \%)\end{array}$ & $\begin{array}{c}0.10 \pm \\
0.03 \\
(62 \%)\end{array}$ & $\begin{array}{c}0.12 \pm \\
0.03 \\
(65 \%)\end{array}$ & $\begin{array}{c}0.11 \pm \\
0.02 * \\
(53 \%)\end{array}$ & $\begin{array}{c}0.13 \pm \\
0.02 \\
(65 \%)\end{array}$ & $\begin{array}{c}0.11 \pm \\
0.04 \\
(50 \%)\end{array}$ & 48.61 & 57.41 & 59.25 & 60.65 & 61.05 & 60.34 \\
\hline VI & $6 f$ & 200 & $\begin{array}{c}0.08 \pm \\
0.06 \\
\end{array}$ & $\begin{array}{c}0.11 \pm \\
0.03 \\
\end{array}$ & $\begin{array}{c}0.09 \pm \\
0.01 \\
\end{array}$ & $\begin{array}{c}0.06 \pm \\
0.01 \\
\end{array}$ & $\begin{array}{r}0.50 \\
\pm .01^{*} \\
\end{array}$ & $\begin{array}{c}0.06 \pm \\
0.01 \\
\end{array}$ & 55.3 & 66.66 & 69.55 & 72.35 & 74.46 & 74.01 \\
\hline & \multicolumn{14}{|c|}{ scoring of Gastric Ulcers } \\
\hline & \multicolumn{14}{|c|}{ Compound Dose mg/ kg. } \\
\hline & \multicolumn{4}{|c|}{ Ulcerogenic response } & score & \multirow{2}{*}{\multicolumn{3}{|c|}{ compound }} & Dose & \multicolumn{3}{|c|}{ Ulcer index \pm S.D } & \multicolumn{2}{|c|}{ Score } \\
\hline & \multicolumn{3}{|c|}{ Ulcers less than $1 \mathrm{~mm}$} & & 100 & & & & & & & & & \\
\hline & \multicolumn{3}{|c|}{ Ulcers less than $1-2 \mathrm{~mm}$} & & 90 & \multicolumn{3}{|c|}{ Control } & & \multicolumn{3}{|c|}{---} & \multicolumn{2}{|c|}{---} \\
\hline & \multicolumn{3}{|c|}{ Ulcers less than 2-3 mm } & & 80 & \multicolumn{3}{|c|}{ Phenyl Butazone } & 50 & \multicolumn{3}{|c|}{$1.85 \pm 0.04$} & \multicolumn{2}{|c|}{50} \\
\hline & \multicolumn{3}{|c|}{ Ulcers less than 3-4 mm } & & 70 & \multicolumn{2}{|c|}{$6 b$} & \multicolumn{2}{|r|}{200} & \multicolumn{3}{|c|}{ nil } & \multicolumn{2}{|c|}{$100 * *$} \\
\hline & \multicolumn{3}{|c|}{ Ulcers less than 4-5 mm } & & 50 & \multicolumn{2}{|r|}{$6 c$} & \multicolumn{2}{|r|}{200} & & $0.58 \pm 0.0$ & & & \\
\hline & & rs less th & $5 \mathrm{~mm}$ & & 25 & \multicolumn{2}{|c|}{$6 e$} & & 200 & & nil & & & ** \\
\hline & & rforated & sions & & 0 & & $6 \mathbf{f}$ & & 200 & & $0.35 \pm 0 . .($ & & & \\
\hline
\end{tabular}

All the test and the standard compounds were suspended in $2 \%$ of acacia solution and administered orally as $0.3 \mathrm{ml} / \mathrm{dose}$ \# Higher the score safer the drug * moderate safety ** Better safety

\section{Conclusions}

Meaningful, safe and economical synthesis of pyrazolyl benzofuran derivatives are synthesized with microwave-assisted green chemical technology. The high yield and the better pharmacological activity and considerable in-vivo tolaratability encourages for the further research in the same line. In the developed series of derivatives, from the structural activity relationship infers that with the chloro substitution to the pyrazolylbenzofuran derivatives enhances the biological activity but with the slight increase in ulcerogicity profile. However it is negligible when compared to the commercially available standard drug, phenylbutazone.

\section{ACKNOWLEDGEMENTS}


Our gratitude to Late Shri. Ghevarchand Suranaji, Managing Director, Micro Labs. Ltd., for the moral support. We acknowledge IISc, Bangalore for providing spectra and Biogenics, Hubli for providing research facilities. Raghunandan Deshpande thank his father for editing.

\section{REFERENCES}

[1] Jennifer, M. K.; Alexander S.; Oliver K. C.; The scale-up of microwave-assisted organic synthesis. Topics in current chemistry. 2006, 266, 233-278.

[2] Baxendale, R. I.; Hayward, J. J.; Ley, S. V. Microwave reactions under continuous flow conditions. Combinatorial chemistry \& high throughput screening. 2007, 10, 802-836.

[3] C'aceres, A.; Jaimes, M.; Ch'avez, G.; Bravo, B.; Ysambertt, F.; M'arquez, N. Continuous system with microwave irradiation to obtain alkyl benzoates. Talanta. 2005, 68, 359-364.

[4] Gareth, S. G., Elander, N.; Stone-Elander, S. A., UV monitoring of microwave- heated reactions, a feasibility study chemistry - A European Journal. 2002, 8, 2255-2260.

[5] William, D.S.; Scott, E. W.; Craig, W. L. Accelerating lead development by microwave-enhanced medicinal chemistry. Drug Discovery Today: Technologies. 2005, 2 (2), 155-161.

[6] Madani, H.; Safouane, M. H.; Tassadit, M.; Baya, B.; Cherifa R.; Farid, C.; and Maâmar, H.; Microwave-assisted synthesis of calix (4) resorcinarenes. Tetrahedron. 2006, 62(24), $5652-5655$.

[7] Edgars, S; Ilga, M. Microwave-assisted heterocyclic chemistry. Microwave in organic chemistry. 2006, 266, 49-101.

[8] Prasad, A.; Eycken, E, V. Microwave-Assisted Natural Product Chemistry. Microwave methods in in organic synthesis. 2006, 266, 1-47.

[9] Kallappa, H. M., Seetharamareddy, Reddy, H., Keri, Rangappa, S., Hanamanthagouda, Manohar, S., Moloney and Mark, G., Microwave assisted, one-pot synthesis of 5-nitro2-aryl substituted-1H-benzimidazole libraries: Screening in vitro for antimicrobial activity. Journal of Enzyme Inhibition and Medicinal Chemistry. 2009, 24(5), 1095-1100.

[10] Anshu, D.; Kapil, A.; Meha S.; Sangeeta G. Microwave assisted green chemical synthesis of novel spiro (indole-pyrido thiazines): a system reluctant to be formed under thermal conditions. Tetrahedron. 2004, 60(24), 5253-5258.

[11] Roberts B. A.; Strauss C. R. Toward Rapid, "Green", predictable microwave-assisted synthesis. Acc. Chem. Res. 2005, $38(8), 653-661$.

[12] Lidström, P.; Tierney, J.; Westman, B. W. J. Microwave assisted organic synthesis - a review. Tetrahedron. 2001, 57 (45), 9225-9283.

[13] Carro, N.; Ignacio, M-C.; Garcia, I. Microwave-assisted extraction and mild saponification for determination of or- ganochlorine pesticides in oyster samples. Analytical and bioanalytical chemistry. 2002, 374, 547-553.

[14] Badami, S.; Ramaswami, S.; Sharma, S.V.; Choksi, R.K.; Dongre, S.H.; Suresh, B. New microwave methods for rapid quantitative ands qualitative analysis and loss on drying, Indian J. Pharma. Sci, 2005, 7(3), 307-310.

[15] Shahar, Y. M.; Mustaqeem, M.; Husain, A.; Afroz B. M.; Erik, D. C.; Synthesis and evaluation of in vitro antiviral activity of 2-(3-(substituted phenyl)-4, 5-dihydro-1H-5- pyrazolyl) benzofuran-3-yl chloride derivatives. Journal of Enzyme Inhibition and Medicinal Chemistry. 2009, 24 (4), 949-956.

[16] El-Diwani, H. I.; Nakkady, S.S.; El-Shabrawy, O.; A-K. M. N.; Gohar, A-K. M. N.; Hishmat, O.H., Reactions of some cinnamoyl benzofuran derivatives with activated nitriles and their biological activity. Archives of Pharmacal Research. 1988, 11(1), 41-44.

[17] Samia, M. R.; Soad, A.; El-Hawash, M.; Hesham, T.Y.; Fahmy, Aly A. Hazza and Mostafa, M. M., El-Meligy. Synthesis and in vitro evaluation of some novel benzofuran derivatives as potential anti-HIV-1, anticancer, and antimicrobial agents. Archives of Pharmacal Research. 2006, 29 (1), 16-25.

[18] Bakr, F. A.; Hatem, A. A.; Essam, M. A. Synthesis and antimicrobial evaluation of 1-(benzofuran-2-yl)-4-nitro-3-ary lbutan-1-ones and

3-(benzofuran-2-yl)-4,5-dihydro-5-aryl-1-(4-(aryl)-1,3-thiaz ol-2-yl)-1H-pyrazoles. European Journal of Medicinal Chemistry. 2009, 44(6), 2632-2635.

[19] Hatem, A. A.; Amal A. I. M. Stereoselective synthesis and antimicrobial activity of benzofuran-based (1E)-1-(piperidin-1-yl)-N2-arylamidrazones. European Journal of Medicinal Chemistry. Article in press, doi:10.1016/j.ejmech.2009.09.002.

[20] Makhsumov, A. G.; Dzhuraev, A. D.; Kilichov, G.; Nikbaev A. T. Antiinflammatory activity of some pyrazole derivatives. Pharmaceutical Chemistry Journal. 1986, 20(3), 289-291.

[21] NCCLS (National committee for clinical laboratory standards). Approved standard A7-M5. Standard methods for dilution antimicrobial susceptibility tests for bacteria, which grows aerobically. Vellinova PA, 1990.

[22] Winter, C.A.; Ris ley, E.A.; Nuss C.W. Carrageenin-induced oedema in hind paw of the rats as an assay for anti-inflammatory drugs. Proc Soc Exp BiolMed. 1962, 111,544-547.

[23] Kamal, M. D.; Hassan, A.; Mohey, E.; Hanan, A.; Mohamed.; Bahira H. Synthesis, anticonvulsant, and anti-inflammatory activities of some new benzofuran-based heterocycles. Archiv der Pharmazie, 2006, 339 (3), 133 - 140.

[24] Cioli, V.; Putzolu, S.; Rossi, V.; Sorza Barcellona, P.; Corradino, $\mathrm{C}$. The role of direct tissue contact in the production of gastro-intestinal ulcers by anti-inflammatory drugs in rats. Toxicol. Appl. Pharmacol. 1979, 50, 283-289. 